\title{
Symbiotic Wisdom: Recovering a Memory of Deep History
}

\author{
Celia Deane-Drummond
}

7320 words including footnotes.

\begin{abstract}
This essay explores the significance of symbiosis and mutualism for a theology of God's action in the world as being through wisdom in the light of evolutionary theories of origin. I argue that theories of evolution that take into account composite entities provide important clues to the evolution of complexity. Further, symbiosis qualifies evolutionary anthropology and contributes to a richer understanding of humanity as both embedded and embodied with other life forms. A Thomistic understanding of memory combines an Aristotelian stress on continuity with an Augustinian interpretation as intellectual understanding and theological insight. Remembering the deep history of our symbiotic past enlarges a theological anthropology and gives pointers towards a theological ethics.
\end{abstract}

\section{Key words}

Symbiosis, mutualism, evolution, composite, Aquinas, theological anthropology.

Biological fashions come and go, and one that is now certainly current and receiving increasing public attention is symbiosis and mutualism.1 Judith Bronstein notes that in

1 I am defining these terms in line with Andrew Davison's definition of symbiosis as simply different organisms "living together", while mutualism is living together in such a way to provide mutual benefit. While this essay will focus on the latter, it is important not to forget completely the darker side of associations through parasitism and other forms of uneven benefit. 
scientific terms, there is "little conceptually orientated literature on mutualism".2

However, that should not give the false impression that mutualism was not routinely part of what natural scientists are taught. I still have clear memories of my biology high school teacher in Oxford in the 1970s inspiring her class with details of botanical research on lichens, nitrogen fixing plants, the importance of endosymbiosis in the origins of eukaryotes, subjects that went on to inspire me to become a natural scientist specializing in botany. Later on in my career as a young plant physiologist in the 1980s working on nitrogen nutrition of plants, I was invited for interview for a tenure track lectureship position at Harvard University in the department of organismal biology on the physiology of Rhizobium/legume relations. 3

The difference now compared with thirty or so years ago is that what was an area of fascination for ecologists and plant physiologists is also contributing to a wider philosophical shift in the way the whole of biology is approached, including evolutionary theory, so that it is less about narrowly defined linear mechanisms of progress of single units, genes, and more about non-linear networks and organic change in whole organisms and systems. Further, in spite of some fascinating details on mutualism that Bronstein covers in her magisterial edited volume, I consider that she is a little too quick to dismiss "philosophical treatises and endless natural history documentaries" in the name of going “deeper" into their scientific importance.4 Such statements could give the false impression that philosophy or history are irrelevant or superficial when trying to

2 Judith Bronstein, ed., Mutualism (Oxford: Oxford University Press, 2015), 1 3 I decided not to pursue as by then the pull towards ecclesial and theological ministry proved too strong and I began theological training the same year, 1987. 4 Bronstein, Mutualism, 1. 
understand both what is going on through the scientific work on mutualism, and elevating its wider significance.

The purpose of this article is to track some of that broader significance, including some of the ways in which these ideas can be appropriated theologically. My focal points in this essay will be (1) the relative coherence of scientific notions of symbiosis with a broader theology of wisdom (2) the contribution of symbiosis to different ways of approaching evolutionary biology which, in turn, has profound significance to the theology and science discussion, and (3) the issues raised by symbiosis on how to understand human identity, and a theological anthropology. For this last area I will draw on a Thomistic understanding of memory, since I believe it helps to clarify how and in what sense humanity can come to an appropriate understanding of ourselves as, in one sense, composite beings.

\section{Symbiotic Wisdom}

\subsection{Historical background}

Historian Douglas Boucher has tracked the way in which mutualism has been appropriated within ecological thought, and believes that the turning point was in the 1970s.5 He uses the highly influential biologist Robert May as a case study. In 1973 he was dismissive of the importance of mutualism to ecosystems, believing that the main

5 Douglas H. Boucher, "The Idea of Mutualism, Past and Future”, in The Biology of Mutualism, ed. Douglas H. Boucher, (London: Croom Hill, 1985), 1-28. 
reason for community stability lay in predator-prey relations. By 1976 he was prepared to suggest that mutualism was "a conspicuous and ecologically important factor in most tropical communities".6 In order to fully understand the significance of this shift close to half a century ago it is important to appreciate broader historical trends in philosophies of nature. Ancient writers, including Aristotle, recognized mutualistic relations between different creatures, such as the plower bird who willingly takes leaches out of crocodile mouths without being hurt.7 Examples such as these were used to support an overall thesis of the balance of nature that held sway for centuries. In medieval societies, including that of Thomas Aquinas, whose work will feature later in this essay, the balance of nature was presupposed to be not only evidence of divine Providence, but also organized according to hierarchical relationships, reflecting the structure of human societies. Further, the hierarchical and balanced and ordered structure of the natural world was a reflection of Divine Wisdom working in creation. 8

6 Boucher, "The Idea", 6

7 Frank N. Egerton's discussion of Aristotle's views is very significant in this respect. He shows how Aristotle draws on Herodius's History (Book 3, Chapters 108-9) where he describes a plover bird taking leeches out of a crocodile, but then elaborates on this in other places, accordingly: "Aristotle liked that story and mentioned it in three different contexts (Historia Animalium, 612a20; De Mirabilibus Auscultationibus, 831al 1-14; Ethica Eudemia, 1236b9), and he also reported that mutualism existed between the bivalve, Pinna, and the crustacean, Pinnotheres (Historia Animalium, 547bl6-17).", F.N. Egerton, "Changing Concepts of the Balance of Nature", Quarterly Review of Biology, 48 (1973), 322-50, 328.

8 Thomas Aquinas accordingly speaks in a Platonic tone when he notes that "To call wisdom mobile is a metaphorical way of saying that wisdom spreads its own likeness through the length and breadth of things. For nothing can exist except it be a sort of reflection deriving from God's wisdom as from its primary operative and formal cause; just as the works of handicraft derive from craftsmanship. Insomuch then as this likeness to divine wisdom is transmitted step by step from the highest things, which share the likeness the most, to the lowest, which share it least, we talk of God's wisdom sallying forth as it were and moving into things" (Summa Theologiae, I, q. 9, a. 2, ad 2), in 
Such an image of God's providential wisdom in the world was shattered in Western societies by the industrial revolution. Thomas Malthus' human population studies, in particular, according to Boucher, introduced the idea that there was a mathematical necessity for a struggle for existence as the real driver behind the creation of a balance in society.9 Herbert Spencer expanded this thesis further by extending it to natural realms, such that struggle and competition were its most basic elements. 10 It is important to note that ideas about a struggle or competition for existence were arising from sources other than Darwinian ones. The idea that progress could only be linked with struggle then, at least in part, influenced Charles Darwin, who, while, in the Origin of Species, did mention mutualisms such as insect pollination or decomposition of leaf litter by earthworms, his theses about adaptation and speciation were reliant upon the concept of competitive relationships.11 However, the late nineteenth century witnessed another

Summa Theologiae 1a. 2-11: Existence and Nature of God, translated by Timothy McDermott (London: New Blackfriars, 1963), 129.

9 Boucher, "The Idea", 9.

10 Boucher's interpretation of Spencer is worth citing in full here, as he interprets Spencer as even more influential in the nineteenth century compared with Charles Darwin. He claims that "Spencer's ideas of struggle and competition as the basic elements of the universe were elaborated in both the natural and social realms, indeed he saw no fundamental difference between them. But while Spencer is justly recognized as the champion of laissez faire and individualism, he felt that the final result of competition is an increasing integration of all members of a society into a differentiated more efficient social organism...Thus competition was ultimately the source of human progress", "The Idea", 10.

11 Charles Darwin, in Origin of Species places the "struggle for life" as the core of his ideas about natural selection, including the premise that "all organic beings are exposed to severe competition" (50), and that "competition should be most severe between allied forms, which fill nearly the same space in the economy of nature" (61, c.f. 94), that competition easing off in extreme situations such as the Arctic or desert regions (62). It was also important in the speciation process as through isolation, immigration and competition is held back (81). Charles Darwin, On the Origin of Species, ed. Gillian Beer (New York: Oxford University Press, 1998). 
social movement in the trade unions in the UK and the mutualite societies in France that stressed the importance of mutual aid. In France, Pierre-Joseph Proudhon's ideas about free credit replacing capitalism 12 led to political upheaval and a massacre that eliminated mutualism, to be replaced subsequently by communism, which, under Marx, tried to unite in political terms the twin ideas of competition and mutualism. It was against this social background that Pierre Van Beneden proposed mutualism in biology in 187313. Often symbiosis and mutualism were used interchangeably. In this period, some twenty years later, authors such as Roscoe Pound criticized what he viewed as "sentimentalism" creeping into discussions, believing that there was no proof that one of the parties was necessarily at an advantage through such an association.14 The Russian Peter Kropotkin tried to get mutualism taken seriously through his book entitled Mutual Aid published at the turn of the twentieth century in 190215 , but his anarchic leanings meant that his work was never widely accepted.16 In the early part of the twentieth century Newtonian ecology was the dominant philosophy, where scientists searched for energy flows and mathematical modeling, assuming mechanistic ecosystems. Boucher argues convincingly that the biological focus on individual entities eventually clashed with a wider sociopolitical focus on systems, encouraging a shift in philosophy of ecology to one that

12 Proudhon's Du Principe Federatif is discussed in Boucher, "The Idea", 11-12. 13 First elaborated as a lecture by Pierre van Beneden to the Royal Society of Belgium on December 16th 1873, "A Word on the Life of Lower Animals", published as "Un Mot Sur La Vie Sociale des Animaux Inferieurs", Bulletin de l'Academie Royale de Belgique, Serie 2, 36 (1873), 779-796.

14 Boucher, "The Idea", 16.

15 Also republished as Peter Kropotkin, Mutual Aid: A Factor in Evolution, translated by Will Jonson (Create Space Independent Publishing Platform, 2014). 16 Boucher, "The Idea", 17. 
stressed group selection, lack of equilibrium, dynamism and flux. Attention to mutualism in ecology was part of this constellation of newer emphases. 17

\subsection{Retrieving an ancient theology of wisdom}

In many respects I concur with Boucher's analysis of the historical trends that have led to the present day interest in mutualism. His approach, however, seems to presuppose that ancient and classical accounts of creation are more or less redundant, left behind in the ashes of the industrial revolution, prior to the emergence of Newtonian science and the shift towards paying proper attention to mutualism once that Newtonian approach proved to be no longer satisfactory. The ancient Hebrew wisdom writers, however, had other contributions to make that show how scientific observations of the natural world are not necessarily incompatible with religious belief. Norman Habel, for example, discusses how an ancient scientific understanding was appropriated in the wisdom school of thought in the wisdom literature of early Israel.18 In his reflection on Proverbs 6.6, Habel notes the importance of direct and careful observation (observe, $r \bar{a} ' \bar{a}$ ) of the natural world as a basic element of what wisdom means.19 This fascination with and attention to

17 While I have discussed this shift in philosophy of ecology in Celia Deane-Drummond, The Ethics of Nature (Oxford: Wiley Blackwell, 2004), 36-38. I did not make explicit a renewed interest in mutualism.

18 Norman Habel has discussed many of these concepts for some time, though his most recent work is summarized in Norman Habel, "Where Can Wisdom be Found: ReDiscovering Wisdom in God's Creation", in The Nature of Things: Re-Discovering the Spiritual in God's Creation, ed. Graham Buxton and Norman Habel (Eugene: Wipf and Stock, 2017), 139-156.

19 The following paragraphs on Habel's work are adapted from a section in Celia DeaneDrummond, Theological Ethics Through a Multispecies Lens: Evolution of Wisdom Volume 1 (Oxford: Oxford University Press, 2019), in press. I do not, however, discuss the explicit biological concepts of symbiosis or mutualism in any detail. This essay is in some ways a companion to ideas worked out in this book. 
what is out there in the world of nature means that paying attention to scientific understanding of the natural world is just as much part of a theology of wisdom as reflections on historical aspects of philosophy and theology. He notes the importance of discernment not just in relation to determining the "way" (derek) or a "place" (māqôm) of a particular phenomenon of nature, but also a way of carefully distinguishing different factors (discern, bîn) through an empirical process. Learning to "acquire" (qānâ) or seek after wisdom is built up over centuries of careful observation.

While it is true, as Habel also notes, that in the cosmology of the wisdom school, everything has its place, and everything has its inner driving force or "way" that does not mean that such arrangements are necessarily hierarchical, even if that was the background assumption of these writers and many following them. In fact, the flow of this literature implies a holistic approach to living things that is at least an improvement on what Boucher terms atomistic Newtonian ecologies, and rather more in line with current ecological philosophy. Living creatures, inanimate forces, and the cosmos as a whole all have their own inner force that make up wisdom as a "way".20 Wisdom literature puts much emphasis on the inner wisdom of wild creatures, including the eagle and the snake (Prov 30.1-3), the wild ass (Job 39.5-8); the wild ox (Job 39. 9-11), and the horse (Job 39.19-25), all of whom challenge the more hierarchical narrative of dominion in Genesis 1.26-28.

In the wisdom traditions everything has its place (māqôm), but what about wisdom as such? Where is the māqôm of wisdom? The answer to this question is found in 20 Norman Habel, Discerning Wisdom in God's Creation: Following the Way of Ancient Scientists (Northcote: Morning Star, 2015). 
Job 28.20 that asks explicitly: "But wisdom, where does she originate? Where is the place of Discernment?" As Habel points out: “The 'place' of Wisdom is a wonder that harks back to its very origins at the time of creation. In the final verses of Job 28, we learn that God is the one who first undertook a successful search for Wisdom. As the divine Sagecum-Scientist, God searched far and wide across Earth to find Wisdom".21 So, in Habel's translation of Job 28.23-24:

God discerned (bîn) her way (derek)

And came to know her place (māqôm),

For God looked to the ends of Earth

And observed $[r \bar{a}, \bar{a}]$ everything under heaven 22

The climax of this poem is "God discovers Wisdom in nature", but that discovery is at the dawn of creation.23 A crucial aspect of this argument is that straight observation is not enough; rather, God in searching for wisdom is discerning the inner character of each phenomenon, or what could possibly be termed the "laws" of nature. After years of studying the wisdom literature, Habel makes the comment that "Wisdom as a natural force in the primordial, as represented in the Wisdom Literature, has no parallel in the other traditions in the Hebrew Scriptures about the creation of the cosmos or the beginning of space, time and matter".24 What is fascinating is that God's acquisition of wisdom is, according to this tradition, prior to the processes of creation as such. So,

21 Habel, "Where can Wisdom?", 147.

22 Habel, "Where can Wisdom?", 147.

23 Habel suggests that this discovery of wisdom is when God is creating meteorological domains, and those domains are representative of the rest of the natural world. Habel, "Where Can Wisdom?", 147-8.

24 Habel, "Where can Wisdom?", 149. 
Proverbs 8.22-23 should be rendered: "Yahweh acquired (qānâ) me first, his way (derek) before his works. From of old, from antiquity I was established, from the first, from the beginnings of Earth". 25 Drawing on a number of interpreters of this text, Habel understands wisdom in this context as implying a "cosmic blueprint" that sets the pattern for other forms of wisdom that subsequently arise in the creative process. Habel contrasts creation as through the divine command, the Word of God, and Wisdom as a cosmic blueprint that is pre-existent and then appropriated by God for the work of creation.26

In many ways, Habel's appeal to wisdom as an innate force driving nature and the whole cosmos has a deep appeal, leading, as it does, to a wondrous amazement at the patterning of the universe and a type of what he terms a "Wisdom consciousness".

However, there is need for some care. First, although originating wisdom is not divine, in Habel's interpretation it is not entirely clear where she comes from, except that in some sense she is pre-existent to the rest of creation.

Second, the forms of wisdom or patterns that we find in the physical realm are not necessarily identical with those in living systems in the way that he implies. Similarly, there are distinctive patterns of wisdom that are specific for different creatures; the rules are only universal in so far as they reflect a common physical and mathematical structure inherent in our universe. But wisdom, in my understanding, is so much more than this physical baseline. It is also about the sheer diversity of life, and its living forms and the

25 Habel, "Where can Wisdom?", 150.

26 Difficult questions arise here as this understanding of wisdom challenges the classical theological notion of creatio ex nihilo. Many biblical scholars reject the latter on the basis of insufficient biblical evidence. At minimum, the wisdom tradition complicates creation out of nothing as being the only appropriate narrative for considering a theology of creation. 
specificity of what wisdom means for each creaturely kind, including, specifically, humans. If the way of the ant or the way of any creature is included, given the argument so far, it is also simultaneously the way of accompanying symbionts, including both parasitic and mutualistic accompaniers. Parasites that are best adapted to their host do not kill them (at least, not immediately) and their "way" is bound up with that of their host for the most part in a semi-stable relationship. Once parasitism becomes overly destructive, then it undercuts the "way" of the host, but in some sense is still bound up with that host in order to survive. Mutualistic symbionts, on the other hand, positively contribute to the "way" of their partners such that the way of the symbiont influences the positive life and flourishing of their partner, and, indeed, vice versa.

\section{Symbiosis and New Evolutionary Theories}

I suggested in the opening remarks that current attention to symbiosis was relevant to current debates on different theories of evolution. Such debates also resonate with newer philosophies of ecology that stress dynamism, flux and change rather than stability or balance of nature. Evolution is, of course, necessarily about change, but debates currently exist as to the relative significance of genetic evolution by natural selection in relation to other forms of inheritance, including for example, that through epigenetics, behavioral and symbolic inheritance.27 At one extreme end of the spectrum, in more popular work,

27 As discussed in Eva Jablonka and Marion Lamb, Evolution in Four Dimensions: Genetic, Epigenetic, Behavioral and Symbolic Variation in the History of Life (Cambridge, MA: MIT Press, 2005). 
Lynn Margulis argues that symbiosis provides the basis for a totally new theory of evolution.28 Her work then influenced James Lovelock's Gaia hypothesis, which understood the planetary system as a living, dynamic organic whole that incorporated the activities of the sum total of biological organisms in keeping the temperature and environmental conditions of the planet constant. 29 It is only in a very loose sense, that the planet as such could be understood as symbiotic. Her more academic work is rather more qualified, focusing on the innovation made possible by symbiosis in speciation and morphogenesis, rather than pressing for a replacement of Darwin's theory of natural selection. 30 At the other end of the spectrum in terms of evolutionary theories standard evolutionary theories (SET) stress a Neo-Darwinian approach influenced by the rise in success of genetics in the twentieth century. According to these theories the basic units of selection are the genes, and the task of evolutionary biology is tracking competition between different genes and their flow as organisms adapt to changing environments. 31 Such positions are coherent if understood as Newtonian in emphasis: the point is to disassemble into the lowest unit that is measureable, namely, the gene. An alternative

28 Lynn Margulis, The Symbiotic Planet: A New Look at Evolution (London: Phoenix, 1998).

29 Space does not permit me to discuss the relative merits of Gaia in this article. For a summary see Deane-Drummond, Ethics of Nature, 162-185. 30 Lynn Margulis and René Foster, Symbiosis as a Source of Evolutionary Innovation: Speciation and Morphogenesis (Cambridge, MA: MIT Press, 1991).

31 As Richard Dawkins notoriously claims in Richard Dawkins, The Selfish Gene (Oxford: Oxford University Press, 2006). 
approach to evolution known as developmental systems theory (DST), as its name implies, is more concerned with changing systems rather than individual units.32

Somewhere in between DST and SET we find extended evolutionary synthesis (EES) theories, which try to take account of both genetic elements and the systems in which they are placed. To put this succinctly, EES allows not just for the evolution of genes by natural selection, but also for the dynamic influences of the environment on those selection processes as well. Hence, it is not simply that the most favorable genes are selected in a given environment through the passive filter of natural selection. Rather, organisms are agents who actively seek out alternative environments and positively construct those environments through what is termed niche construction. 33 This modified environment is then inherited by the next generation alongside the genes. That environment can, in addition, include other biological species as well as a variety of cultures and traditions specific to different species that are learned. Niche construction theory is, therefore, a crucial aspect of evolutionary change that takes up ecological ideas of "niche" and weaves that concept into a holistic and systems based understanding of inherited changes in organisms through time. Further, given the importance of niche construction in evolutionary terms, there are further implications for a more fundamental understanding of the relationships between different organisms and their environments 34 ,

32 There is insufficient space to go into the details of the different theories in this article, but I have discussed these alternatives in some depth in Deane-Drummond, Theological Ethics, in press.

33 See for example, Kevin N. Laland, F. John Odling-Smee, and Marc W. Feldman. "Cultural Niche Construction and Human Evolution", Behavioral Brain Sciences 23 (2000): 131-75.

34 I discuss niche construction theory in a number of different places, but most recently in Celia Deane-Drummond, "A Theory of Niche Construction for the Twenty First 
since it is not just genes that are inherited, but environments, and those environments, of course, includes symbionts.

My own view is that within this spectrum of different evolutionary hypotheses EES makes the most sense, and it is in this context that I will discuss the contribution of symbiosis to evolutionary theories. At the outset, I think it is important to point out, as many plant physiologists know only too well, whether a symbiotic relationship becomes mutualistic or not depends on specific conditions. Symbiosis, on this basis, is better defined as the means through which organisms gain access to novel metabolic capacities, such as photosynthesis, nitrogen fixation and cellulose degradation. 35 This definition could include even those associations of short duration, such as insect pollination of flowering plants, even though Anton de Bary in the mid nineteenth century excludes such associations in his definition of symbiosis as a "living together of different species".36

Angela Douglas rejects the idea that symbiosis improves fitness of an organism on the basis that fitness is a comparison between two different organisms in the same environment, rather than a single organism in two environments: a non-associative environment or an associative environment.37 Plant physiologists can manipulate that environment in laboratory conditions, so that green hydra, for example, will expel their associated green algae under some conditions of temperature and light. 38 One of the difficulties in such interpretations, however, is how best to understand the baseline

Century", in Theology and Ecology Across the Disciplines, ed. Celia Deane-Drummond and Rebecca Artinian Kaiser (London: Bloomsbury, 2018), 241-56. 35 Angela E. Douglas, Symbiotic Interactions (Oxford: Oxford University Press, 1994). 36 Douglas, Symbiotic Interactions, 1.

37 Douglas, Symbiotic Interactions, 2-3. 38 Douglas, Symbiotic Interactions, 3. 
organism. Douglas seems to have presupposed a disassociated baseline model but the extent to which symbionts are present will reflect whether that is likely to be correct or not. At least $75 \%$ of all vascular plant species bear vesicular-arbuscular mycorrhizas. She admits herself that "The varied mycorrhizal associated probably evolved at the time of origin of their plant partners, the ectomycorrhizas with the gymnosperms in the late Palaeozoic, the archid mycorrhizas with the Orchidaceae in the Cretaceous and the ericoid mycorhizas with the Ericoceae in the early Tertiary". 39 However, if that is the case, if the evolutionary origin of a given organism is bound up so tightly with another species such that its existence has never been without it and may be impossible without it, , does it still make any sense to speak about evolutionary fitness in isolation of the symbiotic partner? Experimentally it is possible to measure growth rates with or without symbionts, and when such experiments are done, associations such as Rhizobium infection of Pisum root nodules, for example, confer mutual advantages where there is a shortage of nitrogen, but not otherwise. 40 In this case different legume genes are also switched on or off depending on the prevailing oxygen conditions.41 Rhizobia are housed in specialist organs called nodules, where cell structure in the outmost nodule periphery is different from the rest of the plant root system. The cells are aligned tightly together in the nodule in such a way that oxygen diffusion is slower. Nitrogen fixation has a very low tolerance of oxygen, so the nodule in effect creates the conditions for nitrogen fixation to occur. However, Rhizobium also needs some oxygen to survive and a specialist oxygen carrier molecule called legohaemoglobin binds and transports oxygen

39 Douglas, Symbiotic Interactions, 19.

40 Douglas, Symbiotic Interactions, 5-6.

41 Douglas, Symbiotic Interactions, 47-54. 
to sites where it is required. At one stage scientists thought that this haemoglobin was somehow incorporated from animals haemoglobin, but the genes appear to be exclusively plant in origin, rather than through a lateral transfer of genes. 42 While the dependence of Rhizobium on the plant to provide conditions for them to fix nitrogen is unusual, it shows the extent to which both species have evolved together and in mutual relationship with each other.

Further back in time at the dawn of the emergence of eukaryotes, free-living cells engulfed bacterial cells, which then became integrated into their structure in a process known as endosymbiosis. These bacteria eventually became incorporated into what are now termed mitochondrial organelles, which have formed the primary basis for chemical energy for eukaryotic cells ever since. Given how far back in time this must have occurred such a theory is necessarily somewhat speculative. However, there is good evidence that this was an integral part of evolutionary history.43 Indeed, biologists Laura Katz and Laura Wegener Parfrey claim that "one of the few certainties in the origin and diversification of eukaryotes is that mitochondria, found in many but not all eukaryotes, are derived from an endosymbiotic alphaproteobacterium." 44 The scientific evidence for this is derived from the fact that the membrane structure and the genome of mitochondria have a close affinity to that of Alphaproteobactea. Mitochondria are also broadly distributed across the phylogenetic tree in all eukaryotes from 2.1-1.7 billion years ago,

42 Douglas, Symbiotic Interactions, $54 \mathrm{ff}$.

43 Laura A. Katz and Laura Wegener Parfrey, "Origin and Diversification of Eukaryotes", in The Princeton Guide to Evolution, ed. Jonathan B. Lasos, (Princeton: Princeton University Press, 2014), 136-142.

44 Katz and Wegener Parfrey, "Origin and Diversification”, 137. 
and those that seem to lack them carry organelles such as hydrogenosomes or mitosomes that seem to be derivative in a secondary sense from mitochondria. 45

The evolution of metabolic interdependence across species is interesting, and as I noted, sometimes is used in definitions of symbiosis. I mentioned the evolution of the Rhizobium/legume association earlier, but flexible and facultative forms of association are also possible between microbial species. The term biologists use for metabolic interdependence is syntrophy. For example, Desulphovibrio vulgaris normally grows in sulphate rich mediums. However, in its absence, if lactate is present along with Methanococcus, D.vulgaris can survive by using enzymes present in Methanococcus. 46 Other interesting developments that are certainly of evolutionary importance are squids that house luminescent bacteria in their ventral surface in order to make them less visible from below against the light. 47 Further, some deep-sea fish have evolved specialist mirrors and lenses to control the emission of light from their symbiotic luminescent bacteria within. 48

Probably one of the most interesting developments in the significance of symbiotic relationships, however, comes from computer simulations of evolutionary theory. Richard Watson argues that certain types of complex system, which could not evolve from a model using standard gradualist frameworks, are possible through what he

45 Katz and Wegener Parfrey, “Origin and Diversification”, 137. 46 J. Peter Gogarten and Lorraine Olendzenski, "Evolution in the Prokaryotic Grade", in The Princeton Guide to Evolution, ed. Jonathan B. Lasos, (Princeton: Princeton University Press, 2014), 131.

47 Gogarten and Olendzenski, "Evolution in the Prokaryotic", 131.

48 Gogarten and Olendzenski, "Evolution in the Prokaryotic", 131 and Douglas, Symbiotic Interactions, 10. 
terms composition, that is, bringing together two separate genetic lineages. 49 One example of this is already part of evolutionary theory and familiar to most people: sex. The other examples is symbiotic encapsulation. He proposes that standard evolutionary theory by natural selection amounts to a hill-climbing model of optimization, which refers to optimization through relative fitness. Thus, in this hill climbing model there is a step by step increment in fitness and those which are incrementally better suited to the current environment survive and reproduce. However, that does not mean that it is the only form of optimization in given conditions. Critically he spells out this issue in the following way:

The real distinction between compositional evolution and gradual evolution is not that one is nongradual and one is gradual, but one is compositional and the other is linear - that is what I refer to as the "gradualist framework of evolution" assumes the linear sequential accumulation of undirected genetic changes (whatever size they may be). 50

The actual compositional events themselves may or may not be beneficial associations, in which case, if they are not beneficial, they clearly will not last. The point is that there are some conditions where, even allowing for non-bias in compositional events, on average such compositional processes are more likely to be beneficial compared with undirected variation produced by mutations. Each compositional event may have prior compositional events preceding it, so the models "support the possibility

49 Richard A. Watson, Compositional Evolution. The Impact of Sex, Symbiosis and Modularity on the Gradualist Framework of Evolution (Cambridge, MA: MIT Press, 2006).

50 Watson, Compositional Evolution, 274. Italics mine. 
that symbiosis potentially produces a fundamentally different source of evolutionary innovation from the accepted norms of evolutionary change".51 The overall result is that what might appear to be impossible complexity in an evolutionary sense becomes feasible through a compositional process. Watson is correct, in my view, to include the standard models associated with evolution by natural selection alongside his stress on composite theories. These results are interesting as it shows that symbiosis is not only ubiquitous and remarkable in many respects in what it can achieve in metabolic terms, but theoretically provides a means to generate a source of innovation that is important to evolutionary theory.

\section{We Are Not Alone}

In this final section I am going to comment on the importance of understanding life forms as compositional. Are Scott Gilbert, Jan Sapp and Alfred Tauber correct to suggest that the prevalence of symbiosis shows that "We have never been individuals"?52 Their argument rests on the assumption that individuality is related to divisions between beings, so where these divisions are broken down or eroded, the individual no longer exists. However, this is only one way of considering the meaning of individuality. In the classic tradition there were two traditions of individuality. One was about difference, but the other was about indivisibility.53 Furthermore, while Thomas Aquinas was certainly fascinated with the notion of distinguishing humanity from other creatures, he understood

51 Watson, Compositional Evolution, 276.

52 Scott Gilbert, Jan Sapp and Alfred I. Tauber, "A Symbiotic View of Life: We Have Never Been Individuals”, The Quarterly Review of Biology 87, no. 4 (2012); 325-341. 53 Jorge I.E. Gracia, "Introduction, The Problem of Individuality", in Individuation in Scholasticism: The Latter Middle Ages and the Counter Reformation 1150-1650, ed. Jorge. I.E. Garcia (New York: State University of New York Press, 1994), 1-20. 
the specific difference associated with human uniqueness in terms of a rational soul that also included incorporation of a plant and animal soul, rather than a strict division from them.54 Each aspect of the soul (vegetative, sensitive and rational) co-existed therefore in a nested hierarchy, rather than being strictly separated. In this light, the basic cause of individuality for him is existence as such, making something a unit that marks it off as distinct from all others. 55 Behind this idea is the Aristotelian framework of the four causes responsible for change, namely, the efficient, formal, material and final. Form is a cause of individuation, but according to the metaphysical notion of essence. He therefore bases his notion of individuation on the exigencies of real form, leaving it open to expansion in terms of life, sentience and rationality, amounting to an indefinite variegation of characteristics in individuals. 56 It becomes, however, rather more difficult to accept Aquinas' hierarchical ordering according to the great chain of Being. But individuality can survive, even if it stretches our imaginations to consider all the microbes that accompany us on our life's journey.

Thomas Aquinas may also have something to say, however, to the particular challenge in considering ourselves in some sense compound or composite individuals. Going back in time, especially to the time of the origins of life, can be difficult to envisage, even disorientating. However, exploring this aspect through his lens of memory may give some tools as to how to manage this difficult task. His work on specific human

54 For further elaboration on this point see Celia Deane-Drummond, "In God's Image and Likeness in Humans and Other Animals: Performative Soul-Making and Graced Nature". Zygon 47.4 (2012), 934-48

55 Joseph Owens, "Thomas Aquinas", in Individuation in Scholasticism: The Latter Middle Ages and the Counter Reformation 1150-1650, ed. Jorge. I.E. Garcia (New York: State University of New York Press, 1994), 173-194. ${ }_{56}$ Owens, "Thomas Aquinas", 188. 
memory is interesting in this respect, since memory is also an essential precondition of practical wisdom or prudence (the bedrock of all natural virtue for Aquinas). Looking back to the deep history of the origins of eukaryotic cells and ultimately our own origins, as every living animal seems to be brimming with millions of microorganisms, takes one's breath away. It is almost unimaginable because we do not have any real tangible sense that other lives are actually embedded in our own. However, just as memory has a way of calling something to mind as if it were really present, and yet we know full well it is not present, so appreciation of symbiosis may be analogous, a leap of a specific pictorial kind that Hans Jonas was fond of referring to when speaking of human uniqueness.57 The point here is that memory allows us to envisage the past in a way that we know is not necessarily true on the present, so gives us tools to bring to our present understanding historical events. We know from scientific evidence that symbiosis is deep in the history of life, but fully appreciating that significance in our own lives and that of other creatures requires not just theoretical knowledge about the microbiome, for example, but also something of a leap of imagination of the kind that Jonas suggests is characteristically human. Mutualism shows that different organisms find their way together, rather than as isolated individuals. Allowing that understanding of a web of life to take hold has profound significance in how we perceive our own way in the world. Memory is also interesting, as without it we do not know how to look ahead. In much the same way, reflecting on the history of life and its fascinating variety of symbioses can

57 I discuss Hans Jonas' understanding of pictorial man in Celia Deane-Drummond, "Practical Wisdom in the Making: A Theological Approach to Early Hominin Evolution in Conversation with Modern Jewish Philosophy", in The Evolution of Human Wisdom, ed. Celia Deane-Drummond and Agustin Fuentes (Lanham: Rowman and Littlefield / Lexington Press, 2017), 167-188. 
help structure how to consider our futures and what priorities need to be at the focus of our ethical concerns. This is, of course, foresight, an essential element for practical wisdom along with memory. Given the fragility of life on planet earth which can be rendered more or less resilient through symbiotic associations, it will take a great deal of practical wisdom to work out which priorities are needed for research.

Thomas Aquinas points out that the specific capacity of human memory, a "quasisyllogistic search among memories of things past in their individuality" is unique to human beings. 58 Given the history of mutualism is also integrated into our own history, the capacity in some sense to imaginatively enter into that history through developing a collective memory is worth exploring in a little more detail. In one sense such an appreciation is also an act of intellectual understanding as well as memory, since it gives an enlarged portrait of human beings in terms of our origins. 59Aquinas' perspective on memory, however, was also influenced by a more Platonic tradition filtered through Augustine's understanding of memory as associated with profound insights of the human mind and its search for and imaging of God.60 Intellectual understanding can therefore originate from memory, and it is this movement from events that happened in the past to an enlargement in human understanding that is relevant to the present discussion.61 Hence, while it may be difficult to appreciate the present reality of millions of other

58 Thomas Aquinas, Summa Theologiae, I, q. 78, a. 4, in Volume 11 (1a. 75-83), Man, translated by Timothy Suttor (London: New Blackfriars, 1970).

59 An Aristotelian view of memory is about accurate recall of past events in living memory as integral to sense experience, rather than an imaginative tracing of the origin of eukaryotic life that was preliminary to human life. 60 See, especially, Aquinas, Summa Theologiae, I, q. 79, a. 6 and a. 7. 61 For a discussion of Augustine's three fold characterization of memory, intelligence and will, and Aquinas' interpretation of intelligence as understanding, which can originate from memory, see Aquinas, Summa Theologiae, I, q. 79, a. 7. 
beings existing in our composite, embedded and embodied existence, an imaginative act of memory that traces a narrative on the origin of life and our own entangled histories fosters such an appreciation as integral to what it means to be human. A step in this process, perhaps, is a clearer recognition of our existing entanglement with other animals that is rather easier to measure and experience.62 Presupposed in such entanglements we discover our life, and that of myriad others, as composite beings. However, that does not necessarily deny our own awareness of individuality.

\section{Tentative Conclusions}

Aquinas believed that one of the conditions required for prudential decisions, for practical wisdom, was memory.63 I have focused in this essay on ways of imagining the life on earth in symbiotic terms as a contribution to theological as well as practical wisdom. This approach also impacts on our understanding of theological anthropology along with a wider awakening to the significance of symbiosis for the whole of the created order. Such processes have the ability to elicit wonder in us and therefore something more profound than can be captured by the scientific narrative alone. While there are still unanswered questions in the science about how such processes might be explained, there remain deeper theological and philosophical questions about what this might mean for our portrait of God, human self understanding and that of creation. Thomas Aquinas insisted on a hierarchical ordering of wisdom, so that those creatures

62 I discuss in some detail in Celia Deane-Drummond, Theological Ethics Through a Multispecies Lens: The Evolution of Wisdom Volume One (Oxford: Oxford University Press, 2019).

63 Thomas Aquinas, Summa Theologiae, II-I, q. 56, a. 5, in Volume 23 (1a2ae. 55-67), Virtue, translated by W.D. Hughes (London: New Blackfriars, 1968). 
that were considered closer to God reflected divine wisdom more accurately. His view of interconnectedness was therefore akin to a ladder of ascent to God through increasingly rational powers, and a ladder of descent in terms of divine presence in the world. A symbiotic wisdom recognizes the ambiguity in symbiotic associations, but also challenges strict adherence to a hierarchical ordering, putting much more emphasis on the vital importance of the most minute of creatures as integrated into composite whole systems. This does not, it seems to me, remove the distinctiveness or individuality of human beings, or other organisms for that matter, and even human uniqueness in some important respects, but it does qualify any sense of human self-importance in the natural world. It therefore encourages not just a memory that we are going to die ("Remember that you are dust", as the Ash Wednesday liturgy spells out), but also, a memory that we are dependent on myriad others living within, that we are composite creatures. This is a memory that is more like an Augustinian sense of understanding that Thomas Aquinas draws on in his work, but it also depends on an Aristotelian view of a continual process of becoming.

From an evolutionary perspective the importance of composite beings cannot be overstated. Theoretical models of evolution are consistent with composite evolution providing a different and complementary pathway to evolutionary history that can account for the origin of complexity rather more readily than the standard linear progression models derived from evolution by natural selection alone. This perspective is another contribution to a wider perception of evolutionary history as being that of systems rather than just single individuals, and reflecting a tendency for cooperation between those individuals that potentially leads to mutual benefit as much as inter- 
competition. While recognizing the risk of parasitism, the overall benefits of mutualistic forms of symbiosis are clear. Further, while due caution should be taken of the naturalistic fallacy, recognition that mutualism is as prevalent as it is in living systems and in evolutionary history of life as a whole can give important clues as to how best to act in ways which are in tune with those processes, and build on them for the common benefit of life on earth. 